\title{
Genetic, sociodemographic and lifestyle factors associated with serum 25-hydroxyvitamin D concentrations in Brazilian adults: the Pró-Saúde Study
}

\author{
Fatores genéticos, sociodemográficos e de \\ estilo de vida nas concentrações séricas de \\ 25-hidroxivitamina $D$ em adultos brasileiros: \\ o Estudo Pró-Saúde
}

\section{Factores genéticos, sociodemográficos y estilo de vida asociados con la concentración sérica 25-hidroxivitamina D en adultos brasileños: Estudio Pro-Salud}

\author{
Flávia Fioruci Bezerra 1 \\ Paula Normando 1 \\ Ana Carolina P. Fonseca 2 \\ Verônica Zembrzuski 2 \\ Mario Campos-Junior 2 \\ Pedro Hernan Cabello-Acero 2 \\ Eduardo Faerstein 3
}

doi: $10.1590 / 0102-311 \times 00287820$

\begin{abstract}
This study aims to investigate factors associated with serum 25-hydroxyvitamin D [25(OH)D] concentration in Brazilian adults considering sociodemographic and lifestyle factors, as well as vitamin D-related single nucleotide polymorphisms (SNPS). This is a cross-sectional study ( $n=491 ; 34-79 y ; 251$ women), nested within a prospective cohort (Pró-Saúde Study). Associations between serum 25(OH)D and sociodemographic characteristics, diet, use of supplement, physical activity, season of blood collection, body fat, skin type, sun exposure index, and SNPs CYP2R1-rs 10741657 and GC-rs 2282679 were explored by multiple linear regression. The prevalence of serum

\author{
Correspondence \\ F. F. Bezerra \\ Instituto de Nutrição, Universidade do Estado do Rio de Janeiro. \\ Rua São Francisco Xavier 524, 12 a andar, Rio de Janeiro, RJ \\ 20550-900, Brasil. \\ flavia.fioruci@gmail.com \\ 1 Instituto de Nutrição, Universidade do Estado do Rio de \\ Janeiro, Rio de Janeiro, Brasil. \\ 2 Instituto Oswaldo Cruz, Fundação Oswaldo Cruz, Rio de \\ Janeiro, Brasil. \\ 3 Instituto de Medicina Social, Universidade do Estado do Rio de \\ Janeiro, Rio de Janeiro, Brasil.
} $25(\mathrm{OH}) \mathrm{D}<50 \mathrm{nmol} / \mathrm{L}$ was $55 \%$. Serum $25(\mathrm{OH}) \mathrm{D}$ was lower among women $(\beta=-4.38 ; 95 \% C I:-8.02 ;-0.74)$, those with higher visceral fat $(\beta=-4.02$; 95\%CI: -5.92; -2.12), and those with AC and CC genotypes for GC-rs 2282679 $(\beta=-6.84$; 95\%CI: $-10.09 ;-3.59 ; \beta=-10.63$; 95\%CI: $-17.52 ;-3.74$, respectively). Factors directly associated with serum 25(OH)D included summer $(\beta=20.14 ; 95 \% \mathrm{CI}: 14.38 ; 25.90)$, intermediate skin type $(\beta=6.16 ; 95 \% \mathrm{CI}$ : 2.52; 9.80), higher sun exposure ( $\beta=0.49$; 95\%CI: $0.22 ; 0.75)$, vitamin $D$ intake $(\beta=0.48 ; 95 \% \mathrm{CI}: 0.03 ; 0.93)$, and physical activity $(\beta=4.65 ; 95 \% \mathrm{CI}$ : $1.54 ; 7.76)$. Besides physical activity, diet, and sun exposure, non-modifiable factors, such as GC genotypes must be considered when evaluating vitamin D insufficiency in mixed-race populations. Moreover, high visceral fat in association with poorer vitamin D status deserve attention given that both conditions are unfavorably related with chronic and acute health outcomes.

Vitamin D; Single Nucleotide Polymorphism; Visceral Fat; Skin Pigmentation 


\section{Introduction}

Over the past decade, the perception of what constitutes an adequate vitamin $\mathrm{D}$ status has been discussed. Previously, vitamin D deficiency was defined by the presence of rickets and osteomalacia, usually associated with very low concentrations of the vitamin D metabolite [25-hydroxyvitamin D; $25(\mathrm{OH}) \mathrm{D}]$, that is the precursor of the hormonal active form 1,25(OH)2D. However, vitamin D status has been extensively investigated in relation to several conditions other than bone diseases and, although most results are inconclusive, some evidence from systematic reviews and meta-analysis indicates its inverse association with insulin resistance and respiratory diseases in different agerange 1,2,3. Additionally, considering that individuals with darker skin are usually more likely to have vitamin D insufficiency ${ }^{4}$ (here defined as serum $\left.25(\mathrm{OH}) \mathrm{D}<50 \mathrm{nmol} / \mathrm{L} 5\right)$, it has been hypothesized that having lower vitamin D concentrations is a possible contributing cause of ethnic-racial health inequalities, penalizing black individuals with greater occurrence and/or severity of chronic kidney disease 6 , insulin resistance 7 , arterial hypertension 8 , among other conditions. Considering research interest and availability of vitamin D status diagnosis, along with unfavorable changes in lifestyle (eg., less physical activity, less sun exposure), reports of vitamin D insufficiency have become a global phenomenon, even in sunny regions $9,10,11$.

Multiple factors seem to influence vitamin D status. Concentrations of vitamin D are usually inversely associated with the female sex, age, darker skin color, lower sun exposure, diet poor in its natural sources, and lack of food fortification 4,12. Epidemiological evidence indicates an inverse association between vitamin D status and obesity; the most acceptable hypothesis to explain this relationship is the sequestration of this fat-soluble vitamin by the adipose tissue 13,14 . Nevertheless, whether fat compartments (visceral and subcutaneous) are differently associated with vitamin D status is still a matter of debate 15,16 . The isolated influence of variation in vitamin D pathway genes or its interaction with environmental factors may also play a role in determining vitamin D status 17,18. Several single nucleotide polymorphisms (SNPs) in genes involved in the synthesis (eg., DHCR7), transportation (eg., GC), and activation/inactivation (eg., CYP2R1 and CYP24A1) of vitamin D have been associated with serum 25(OH)D concentration 19,20,21,22. Particularly, the C allele for rs 2282679 (GC gene) and G allele for rs 10741657 (CYP2R1) have been associated with higher risk for vitamin D insufficiency 20,21,22.

Few studies have simultaneously investigated the role of sociodemographic, lifestyle, and genetic determinants of vitamin D concentrations in ethnically heterogeneous populations 15,17,23,24,25, and no such studies have been previously conducted among Brazilians adults with highly mixed racial/ ethnic origins. Understanding vitamin D determinants among Brazilian adults may contribute to identify subgroups of individuals more susceptible to vitamin D insufficiency and therefore to its health implications. We investigated factors associated with vitamin D concentrations in Brazilian adults, considering sociodemographic characteristics, level of sun exposure, body composition, physical activity practice, and nutritional factors, as well as genetic polymorphisms.

\section{Methods}

\section{Study design and population}

This cross-sectional study is nested within the Pró-Saúde Study, a prospective cohort study with the civil servants from a university in Rio de Janeiro, Brazil, focusing on the investigation of social determinants of health and health-related behavior ${ }^{26}$. Details on study population and design were previously described 27,28. Briefly, four waves of data collection have been conducted among 3,253 participants $(1999,2001,2006$, and 2012). In parallel with wave 4, a subset of 520 participants of wave 1 (baseline) randomly selected within strata of sex, age (less than 50 years vs. 50 years or more), and educational level (less than high school vs. high school or more), were invited to perform additional interviews, addressing use of medication (including vitamin supplements) and a food frequency questionnaire (FFQ). Additionally, participants' body composition and skin pigmentation were assessed, and blood samples $(20 \mathrm{~mL})$ were collected after an overnight fast. Serum was separated, aliquoted in 
polypropylene tubes and stored at $-80^{\circ} \mathrm{C}$ until laboratory analysis. Data collection occurred between July 2012 and October 2013.

Six participants did not perform blood collection, eight had insufficient material for DNA extraction and five participants did not perform body composition measurements. Additionally, seven participants had incomplete sociodemographic and/or physical activity practice information. Also, three participants were excluded due to extreme high serum 25(OH)D concentrations ( $>125 \mathrm{nmol} / \mathrm{L}$; sample collected during winter/autumn months, no supplement uses), thus 491 participants with overall complete information were included in the current analysis. This study was registered in the National Research Ethics System, approved by the Research Ethics Committee of the Social Medicine Institute at the State University of Rio de Janeiro. All participants provided written informed consent.

\section{Serum 25(OH)D assessment}

Serum 25(OH)D concentration (nmol/L) was determined using a semiautomated chemiluminescent enzyme-labeled immunometric assay (Liaison, Diasorin; https://www.diasorin.com). The manufacturer reports an analytical range of $4-150 \mathrm{ng} / \mathrm{mL}(10-375 \mathrm{nmol} / \mathrm{L})$. All samples were analyzed in duplicate, and if duplicates differ by $10 \%$, the sample was aßayed once again. Intra- and inter-assay coefficients of variation were $4.9 \%$ and $5.8 \%$, respectively. Details on assay performance were previously described 27 . Vitamin D insufficiency was defined as serum 25(OH)D lower than 50nmol/L 5 .

\section{Potential associated variables}

Sex, age, educational level (categorized as primary education or less, secondary, college or more) were analyzed in addition to the following potential factors selected on the basis of published evidence of their associations with serum $25(\mathrm{OH}) \mathrm{D}$ concentrations:

- Season of the year - Date of blood collection was recorded and categorized in spring (SeptemberNovember), summer (December-February), autumn (March-May) and winter (June-August) months; - Body mass index (BMI) - Standing height $(\mathrm{m})$ and body weight $(\mathrm{kg})$ were measured using a stadiometer (Seca; https://www.seca.com) and a calibrated electronic scale (Filizola; http://www.oswaldofilizola.com.br/), respectively. BMI $\left(\mathrm{kg} / \mathrm{m}^{2}\right)$ was calculated and categorized according to the World Health Organization (WHO) cutoff values ${ }^{29}$. Due to their reduced number, participants classified as "underweight" $(\mathrm{n}=4)$ were grouped together with participants classified as "normal";

- Body fat - Total body fat mass was measured using a dual-energy X-ray absorptiometry (DXA) scanner (iDXA, GE; https://www.gehealthcare.com.br/) using enCORE software version 12.20. Scanning was performed by two trained operators and then analyzed by the same certified clinical densitometrist (CCD, ISCD). Subcutaneous adipose tissue (SAT) and visceral adipose tissue (VAT) were estimated using the software CoreScan VAT. The software only records the VAT information; in order to explore its influence on serum $25(\mathrm{OH}) \mathrm{D}$ concentrations, SAT was calculated by subtracting VAT from total fat mass;

-Vitamin D dietary intake - A previously validated FFQ ${ }^{30}$ was applied by trained nutritionists and used to estimate vitamin $\mathrm{D}$ intake. Participants were requested to indicate the consumption frequency (eight options ranging from $\geq 3$ times/day to never or almost never) and the average daily amount for 81 food items 28 . The amount of vitamin D consumed ( $\mu \mathrm{g} /$ day) was calculated using data based on the food composition table from the U.S. Department of Agriculture 31;

- Use of vitamin D supplements - The identification of medicines and supplements containing vitamin D in their formulation was carried out based on the responses to two different questions: firstly, from an open-ended question on medication use in the previous week; secondly, from another openended question on current osteoporosis treatment. Both questions asked only for yes/no responses, thus no details on timing and dose were included. A positive answer to either question was recorded as "yes";

- Physical activity - Information on physical activity practice was obtained with a dichotomous (yes/ no) question: "In the last two weeks, have you practiced any physical activity to improve your health, physical condition, or for aesthetic purposes or leisure?”; 
- Constitutive and facultative skin pigmentation - Skin pigmentation was measured using a portable reflectometer (Chroma Meter CR-400, Konica Minolta; https://www.konicaminolta.com), in two parts of the body: at the upper underarm, generally not exposed to sunlight (constitutive pigmentation), and at the dorsum of the hand (facultative pigmentation). The upper underarm measures of luminance $\left(\mathrm{L}^{*}\right)$ and the yellow-blue component $\left(\mathrm{b}^{*}\right)$ in the $\mathrm{L}^{*} \mathrm{a}^{*} \mathrm{~b}^{*}$ color space system (Commission Internationale de l'Eclairage, 1976; http://www.cie.co.at/cie/) were used to calculate the individual typology angle (ITA). The ITA value enabled the classification of the type of skin into six groups (very light, light, intermediate, tanned, brown, and dark) 32 . Few participants were classified as very light $(\mathrm{n}=18)$ and dark $(\mathrm{n}=12)$, therefore they were grouped together with those classified as light and brown, respectively, resulting in four constitutive types of skin categories. The Sun Exposure Index (SEI) was calculated as the luminance $\left(\mathrm{L}^{*}\right)$ difference between facultative and constitutive pigmentation, divided by constitutive pigmentation multiplied by 100 33, and used as a measure of cumulative sun exposure;

- Genotyping - DNA samples were isolated from whole blood using a commercial kit (Puregene Blood Kit - Qiagen; https://www.qiagen.com). The quality and concentration of DNA were evaluated by spectrophotometry (BioDrop DUO, BioDrop; http://biochrom.co.uk). After extraction, DNA samples were stored at $-80^{\circ} \mathrm{C}$, until genotyping. Candidate genes explored in this study were selected from genome-wide association studies (GWAS) of vitamin D 20,22. Our genotyping was limited to four polymorphisms in NADSYN1/DHCR7, CYP2R1, CYP24A1, and GC, for which the associations of common variants with serum concentrations of vitamin D have been confirmed 20,22. Genotyping was performed by real-time PCR (StepOnePlus Real-Time PCR System, Thermo Fisher Scientific Inc.; http://www.thermofisher.com/), and allelic discrimination using TaqMan assays (Thermo Fisher Scientific Inc.), to analyze the SNPs rs12785878 (G>T), rs10741657 (A>G), rs6013897 (A>T) and rs2282679 (A>C) of the NADSYN1, CYP2R1, CYP24A1 and GC genes, respectively. Results were analyzed using the SDS 2.3 software (Thermo Fisher Scientific Inc.).

\section{Data analyses}

Continuous variables were summarized as median and interquartile range (IQR) or means and standard deviations (SD) and categorical variables as frequencies and percentages. Genotypic frequencies for each SNP were assessed for Hardy-Weinberg equilibrium using the $\chi^{2}$ test. The SNPs NADSYN1rs12785878 and CYP24A1-rs6013897 did not respect the Hardy-Weinberg equilibrium, and therefore were excluded from the analysis. Mann-Whitney and Kruskal-Wallis with pairwise comparisons by Dunn's post hoc test were used to compare 25(OH)D means in categories of independent variables. Spearman's correlation coefficients were calculated between serum 25(OH)D and independent continuous variables. After checking the premises attainment 34, multiple linear regression with backward elimination of statistically nonsignificant $(p>0.05)$ variables was used to explore factors associated with serum 25(OH)D. The following variables were tested: Model 1 - sex, age (years, continuous), educational level (three categories), visceral fat mass ( $\mathrm{kg}$ ), subcutaneous fat mass $(\mathrm{kg})$, skin type (four categories), sun exposure index (continuous), use of vitamin D supplement (yes vs. no), vitamin D dietary intake (mg/day), physical activity practice (yes vs. no) and month of blood draw (four categories); Model 2 - variables included in model 1 added by genotypes derived from single nucleotide polymorphisms (CYP2R1-rs10741657, GC-rs2282679). Statistical analyses were conducted using SPSS, version 22.0 (https://www.ibm.com/) and statistical significance was set at $\mathrm{p}<0.05$.

\section{Results}

The descriptive characteristics of the participants and mean concentrations of serum 25(OH)D by each categorical variable are presented in Table 1 . About half (51.1\%) of the participants were women, predominantly between 45-54 years old (43.8\%), with college education attainment (55.2\%) and classified as very light or light skin type (33.8\%). Overweight and obesity were highly prevalent (41.8 and $29.9 \%$, respectively) based on BMI categories. Few participants (6.9\%) were current users of vitamin D supplements. The dietary intake of vitamin D was on average $5.3 \mu \mathrm{g} /$ day $(212 \mathrm{IU} /$ day). 
Table 1

Descriptive characteristics of the study population and mean serum 25-hydroxyvitamin D [25(OH)D] concentration according to its categories. Pró-Saúde Study, Brazil, 2012-2013.

\begin{tabular}{|c|c|c|c|c|c|c|c|}
\hline \multirow[t]{2}{*}{ Characteristics } & \multirow[t]{2}{*}{$\mathbf{n}$} & \multirow[t]{2}{*}{$\%$} & \multicolumn{3}{|c|}{ 25(OH)D (nmol/L) } & \multicolumn{2}{|c|}{ Frequency of insufficiency $(<50 \mathrm{nmol} / \mathrm{L})$} \\
\hline & & & Median & IQR & p-value * & $\%$ & p-value ** \\
\hline Sex & & & & & 0.075 & & 0.160 \\
\hline Male & 240 & 48.9 & 49.1 & 25.5 & & 52.5 & \\
\hline Female & 251 & 51.1 & 46.1 & 26.4 & & 57.4 & \\
\hline Age group (years) & & & & & 0.409 & & 0.519 \\
\hline$<45$ & 110 & 22.4 & 49.5 & 20.9 & & 51.8 & \\
\hline $45-54$ & 215 & 43.8 & 46.9 & 28.0 & & 58.6 & \\
\hline $55-64$ & 139 & 28.3 & 48.9 & 28.0 & & 53.2 & \\
\hline$\geq 65$ & 27 & 5.5 & 50.1 & 28.8 & & 48.1 & \\
\hline Educational level & & & & & 0.684 & & 0.924 \\
\hline Primary or less & 49 & 10.0 & 49.5 & 31.9 & & 53.1 & \\
\hline Secondary & 171 & 34.8 & 48.1 & 28.0 & & 54.4 & \\
\hline College or more & 271 & 55.2 & 47.6 & 25.3 & & 55.7 & \\
\hline Body mass index *** & & & & & $<0.001$ & & $<0.001$ \\
\hline Underweight/Normal & 139 & 28.3 & $54.8^{a}$ & 23.1 & & 36.7 & \\
\hline Overweight & 205 & 41.8 & $45.1 \mathrm{~b}$ & 27.1 & & 61.5 & \\
\hline Obesity & 147 & 29.9 & $43.8 \mathrm{~b}$ & 23.4 & & 63.3 & \\
\hline Skin type \# & & & & & 0.005 & & 0.059 \\
\hline Very light/Light & 166 & 33.8 & $47.7 a, b$ & 28.5 & & 54.2 & \\
\hline Intermediary & 129 & 26.3 & $48.9 a$ & 22.6 & & 54.3 & \\
\hline Tanned & 104 & 21.2 & $51.2 \mathrm{a}$ & 28.0 & & 47.1 & \\
\hline Brown/Dark & 92 & 18.7 & $40.6 b$ & 28.3 & & 66.3 & \\
\hline Season of blood draw & & & & & $<0.001$ & & $<0.001$ \\
\hline Winter & 183 & 37.3 & $42.6^{a}$ & 24.2 & & 64.5 & \\
\hline Spring & 130 & 26.5 & $48.3 b$ & 29.2 & & 54.6 & \\
\hline Summer & 43 & 8.8 & $60.9 c$ & 26.9 & & 23.3 & \\
\hline Autumn & 135 & 27.5 & $49.4 b$ & 24.0 & & 52.6 & \\
\hline Use of vitamin D supplement & & & & & 0.213 & & 0.093 \\
\hline No & 457 & 93.1 & 47.8 & 26.6 & & 56.0 & \\
\hline Yes & 34 & 6.9 & 52.9 & 29.8 & & 41.2 & \\
\hline Physical activity & & & & & 0.005 & & 0.007 \\
\hline No & 288 & 58.7 & 45.4 & 25.9 & & 60.1 & \\
\hline Yes & 203 & 41.3 & 50.3 & 27.3 & & 47.8 & \\
\hline
\end{tabular}

IQR: interquartile range.

Note: for each variable, different superscript letters indicate significant difference in serum 25(OH)D concentrations between categories (pairwise comparisons by Dunn's post-hoc test, $\mathrm{p}<0.05$ ).

* p-values for comparison between categories by Mann-Whitney or Kruskal-Wallis test;

** Chi-square test;

*** Body mass index $\left(\mathrm{kg} / \mathrm{m}^{2}\right)$ categories according to World Health Organization 29. Participants classified as "underweight" $(n=4)$ were added to the "normal" category;

\# Skin type categories based on Individual Typology Angle (ITA) value, according to Del Bino et al. 32. 
In the overall population, median value for serum $25(\mathrm{OH}) \mathrm{D}$ concentration was $48.1 \mathrm{nmol} / \mathrm{L}$ (IQR 26.8, mean 48.0, SD $19.1 \mathrm{nmol} / \mathrm{L})$. Serum 25(OH)D concentration was lower among overweight/ obese ( $<<0.001)$, brown or dark skin type $(\mathrm{p}<0.01)$, those who were assessed during winter months $(\mathrm{p}<0.001)$, and those who reported no physical activity practice in the last two weeks $(\mathrm{p}<0.01)$ (Table 1). No statistically significant differences in mean serum 25(OH)D were observed across sex, age, and education categories; also, use of vitamin D supplements was not associated with serum concentrations of vitamin D.

Mean values of continuous variables and their respective Spearman's correlation coefficients for the association with serum 25(OH)D concentrations are shown in Table 2. Statistically significant inverse correlations were observed between serum 25(OH)D and BMI and fat mass (both visceral and subcutaneous) $(\mathrm{p}<0.001)$. Serum 25(OH)D was also directly correlated with sun exposure index $(\mathrm{p}<0.001)$. Vitamin D dietary intake was not significantly correlated with serum $25(\mathrm{OH}) \mathrm{D}(\mathrm{p}=0.321)$. The gene $G C$, which encodes vitamin D binding protein, was significantly associated with vitamin $\mathrm{D}$, with lower serum 25(OH)D concentrations being observed in those individuals carrying the C allele for rs2282679 (p<0.01) (Table 3).

\section{Table 2}

Measures of adiposity, sun exposure and vitamin D intake of the study population and their association with serum 25-hydroxivitamin D [25(OH)D] concentration. Pró-Saúde Study, Brazil, 2012-2013.

\begin{tabular}{lcccc}
\hline Independent variables & Mean & SD & Correlation with serum 25(OH)D * \\
& & & R & p-value \\
\hline Body mass index $\left(\mathrm{kg} / \mathrm{m}^{2}\right)$ & 27.9 & 4.9 & -0.240 & $<0.001$ \\
Visceral fat mass $(\mathrm{kg})$ & 1.33 & 0.87 & -0.160 & $<0.001$ \\
Subcutaneous fat mass $(\mathrm{kg})$ & 26.9 & 9.3 & -0.266 & $<0.001$ \\
Sun exposure index & 11.3 & 6.4 & 0.207 & 0.001 \\
Dietary vitamin D intake $(\mu \mathrm{g} /$ day) & 5.4 & 3.4 & 0.045 & 0.321 \\
\hline
\end{tabular}

SD: standard deviation.

* Spearman correlation coefficients and p-values for the association between independent variables and serum 25(OH)

D concentrations.

Table 3

Genotypic frequencies of the studied single nucleotide polymorphisms (SNPs) and serum 25-hydroxivitamin D [25(OH)D] concentrations according to genotypes. Pró-Saúde Study, Brazil, 2012-2013.

\begin{tabular}{|c|c|c|c|c|c|c|c|}
\hline \multirow[t]{2}{*}{ Gene/SNP } & \multicolumn{2}{|c|}{ Genotype frequencies } & \multicolumn{3}{|c|}{ 25(oh)D (nmol/L) } & \multicolumn{2}{|c|}{ Frequency of insufficiency ( $<50 \mathrm{nmol} / \mathrm{L})$} \\
\hline & $\mathbf{n}$ & $\%$ & Median & IQR & p-value & $\%$ & p-value * \\
\hline \multicolumn{8}{|l|}{ CYP2R1 } \\
\hline $\operatorname{rs} 10741657(A>G)$ & & & & & 0.118 & & 0.119 \\
\hline $\mathrm{AA}$ & 44 & 9.0 & 49.5 & 22.8 & & 56.8 & \\
\hline GA & 202 & 41.1 & 50.0 & 28.3 & & 49.5 & \\
\hline GG & 245 & 49.9 & 46.0 & 25.6 & & 59.2 & \\
\hline \multicolumn{8}{|l|}{ GC } \\
\hline $\mathrm{rs} 2282679(\mathrm{~A}>\mathrm{C})$ & & & & & $<0.001$ & & $<0.001$ \\
\hline AA & 299 & 60.9 & $50.3^{a}$ & 28.3 & & 48.2 & \\
\hline$A C$ & 166 & 33.8 & $44.4 b$ & 21.9 & & 65.7 & \\
\hline $\mathrm{CC}$ & 26 & 5.3 & $38.6 \mathrm{~b}$ & 27.2 & & 65.4 & \\
\hline
\end{tabular}

IQR: interquartile range.

Note: for each SNP, different superscript letters indicate significant difference between genotypes by Kruskal-Wallis (pairwise comparisons by Dunn's post hoc test, $\mathrm{p}<0.05$ ).

* Chi-square test. 
Prevalence of vitamin D insufficiency was of 55\% in the overall study population, and significantly different between the categories of BMI, seasons, physical activity, and GC-rs2282679 genotypes (chisquare, $\mathrm{p}<0.05$ ) (Tables 2 and 3). Prevalence of insufficiency was particularly high among individuals with overweight (61.5\%) or obesity (61.3\%), with brown or dark skin type (66.3\%), who participated in the study during winter (64.5\%), with no physical activity (60.1\%), and carrying AC (65.7\%) or CC (65.4\%) genotypes (Tables 2 and 3).

In multiple regression models, female sex and higher visceral fat mass were independently associated with lower serum concentrations of 25(OH)D; whereas spring, summer, and autumn months (winter as reference), intermediate and tanner skin types (very light and light as reference), being physically active in the last two weeks, higher dietary vitamin D intake and higher sun exposure index were directly associated with higher concentration of serum 25(OH)D (Table 4, model 1). All these nongenetic parameters were kept in the model when SNPs were included (Table 4, model 2). The GCrs2282679 was the only SNP associated with serum 25(OH)D; with genotypes carrying at least one C allele being associated with lower concentrations of the vitamin.

Table 4

Factors associated with serum 25-hydroxivitamin D [25(OH)D] concentrations. Pró-Saúde Study, Brazil, 2012-2013.

\begin{tabular}{|c|c|c|c|c|}
\hline \multirow[t]{2}{*}{ Independent variables * } & \multicolumn{2}{|c|}{ Model 1 ** } & \multicolumn{2}{|c|}{ Model $2 * * *$} \\
\hline & $\beta$ & $95 \% \mathrm{Cl}$ & $\beta$ & $95 \% \mathrm{Cl}$ \\
\hline \multicolumn{5}{|l|}{ Sex } \\
\hline Male & Reference & - & Reference & - \\
\hline Female & -3.895 & $-7.608 ;-0.181$ & -4.379 & $-8.020 ;-0.737$ \\
\hline \multicolumn{5}{|l|}{ Skin type } \\
\hline Very light/Light & Reference & - & Reference & - \\
\hline Intermediate & 5.526 & $1.824 ; 9.228$ & 6.157 & $2.520 ; 9.795$ \\
\hline Tanned & 5.383 & $1.388 ; 9.377$ & 5.567 & $1.652 ; 9.482$ \\
\hline \multicolumn{5}{|l|}{ Month of blood draw } \\
\hline Winter & Reference & - & Reference & - \\
\hline Spring & 6.083 & $2.133 ; 10.034$ & 5.895 & $2.022 ; 9.767$ \\
\hline Summer & 20.349 & $14.466 ; 26.233$ & 20.137 & $14.375 ; 25.900$ \\
\hline Autumn & 5.708 & $1.828 ; 9.588$ & 4.772 & $0.945 ; 8.600$ \\
\hline Sun exposure index & 0.488 & $0.215 ; 0.760$ & 0.486 & $0.219 ; 0.753$ \\
\hline Visceral fat mass & -4.127 & $-6.067 ;-2.188$ & -4.017 & $-5.917 ;-2.117$ \\
\hline Vitamin D dietary intake & 0.482 & $0.022 ; 0.942$ & 0.480 & $0.029,0.931$ \\
\hline \multicolumn{5}{|l|}{ Physical activity } \\
\hline No & Reference & - & Reference & - \\
\hline Yes & 4.411 & $1.236 ; 7.586$ & 4.650 & $1.537 ; 7.762$ \\
\hline \multicolumn{5}{|l|}{ GC-rs2282679 } \\
\hline AA & - & - & Reference & - \\
\hline$A C$ & - & - & -6.840 & $-10.093 ;-3.586$ \\
\hline $\mathrm{CC}$ & - & - & -10.633 & $-17.523 ;-3.744$ \\
\hline
\end{tabular}

95\% Cl: 95\% confidence interval.

* Independent variables retained in the final model after backward elimination of those nonsignificant $(p>0.05)$ in the multiple regression analysis;

** Model 1: sex, age (years), educational level (three categories), visceral fat mass (kg), subcutaneous fat mass (kg), skin type (four categories), sun exposure index, use of vitamin D supplement (yes vs. no), vitamin D dietary intake ( $\mu$ g/day), physical activity (yes vs. no), and month of assessment (four categories);

*** Model 2: variables included in model 1 added by genotypes derived from single nucleotide polymorphisms (CYP2R1-rs10741657, GC-rs2282679). 


\section{Discussion}

A number of studies have examined nongenetic factors associated with vitamin D concentrations in different adult populations, including Brazilians 35 , and few have explored genetic determinants. The simultaneous exploration of demographic, lifestyle, and genetic factors has been even less frequent $15,17,23,24,25$ and, to our knowledge, this is the first investigation of its kind among Brazilian adults. Although participants were living in a city mostly sunny throughout the year (latitude $22^{\circ} 58^{\prime}$ S), season still appeared as an important factor associated with $25(\mathrm{OH}) \mathrm{D}$ in multiple regression models, in addition to individual sun exposure, fat mass accumulation, skin type, physical activity, vitamin D dietary intake, and genetic markers. The use of vitamin D supplements was not associated to $25(\mathrm{OH})$ D concentrations.

Serum $25(\mathrm{OH}) \mathrm{D}$ concentrations in the present study varied widely $(10-120 \mathrm{nmol} / \mathrm{L})$ with mean values similar to studies conducted in different countries, including those less favored by sunlight incidence 15,23 . We found that more than half $(\sim 55 \%)$ of the participants had $25(\mathrm{OH}) \mathrm{D}$ concentrations below $50 \mathrm{nmol} / \mathrm{L}$, the most accepted reference value to define vitamin D insufficiency ${ }^{5}$. In a Brazilian geospatial meta-analysis including different age groups, whether healthy or not, a large variation $(<1 \%$ to $80 \%)$ in frequency of vitamin $\mathrm{D}$ values $<50 \mathrm{nmol} / \mathrm{L}$ was observed, with an overall reported prevalence of vitamin D insufficiency of $28.16 \%$ (95\%CI: 23.90; 32.40), being higher in Southeastern (where Rio de Janeiro is located) and Southern regions of the country 36. It is also important to highlight that less than $10 \%$ of our study population was assessed during summer months, which may have contributed to the high overall prevalence of vitamin D insufficiency. The notion of being a sunny region often leads to underestimation of season relevance when evaluating vitamin $\mathrm{D}$ status. However, the frequency of insufficiency varied from $\sim 25 \%$ in summer months to around $65 \%$ in the winter months.

It is well accepted that serum $25(\mathrm{OH}) \mathrm{D}$ concentration is determined by several lifestyle factors, especially sun exposure, physical activity, and diet. The relative contribution of diet appears to be more relevant in countries with low sun availability and where natural vitamin D food sources are strongly integrated with dietary habits of the population, such as the consumption of fatty fish by the Nordics ${ }^{37}$. For several Northern countries, fortified foods have become an almost essential vitamin D source. A typical Brazilian diet, notwithstanding important regional variations, is generally poor in natural rich vitamin D sources. Also, vitamin D fortified foods are very restricted in Brazil and do not appear to contribute importantly to overall vitamin D intake ${ }^{38}$. Consistently, the estimated average intake in our study corresponded to about one-third of that currently recommended $(15 \mu \mathrm{g} /$ day or $600 I U /$ day) for adults under conditions of minimal sun exposure 5 . In spite of that, our results suggest that a habitually higher dietary intake indeed contributed to increase vitamin $\mathrm{D}$ concentrations. The use of supplements, however, did not. Taking vitamin D supplements frequently appear as a determinant of vitamin D status in other countries 39,40 . Very few participants made use of vitamin D supplement, which may have contributed to the lack of influence of the use of supplements on vitamin D concentrations. Regarding physical activity, it was also directly associated with vitamin D concentrations, as previously observed 15,23 . Although it was previously suggested that exercise itself may affect vitamin D concentrations 41 , it is well accepted that its influence results from a combination of lower fat accumulation among active people and higher sun exposure during outdoor activity 12,15,23,24.

Estimations on the relative contribution of cutaneous synthesis for the overall content of vitamin $\mathrm{D}$ in the body may reach $80 \%$ depending on both environmental and individual factors 42 . Zenith angle of the sun, air quality, and nebulosity are all factors that influence the potential of a given geographic location in subsiding good conditions for vitamin D synthesis. The duration and amount of skin exposed to UVB rays also matter ${ }^{43}$. Furthermore, individual barriers to UVB penetration such as thickness and darker skin color are added to this complex set of factors involved in determining the efficiency of vitamin D synthesis 43 . The actual relative contribution of cutaneous synthesis is therefore difficult to estimate. However, it may benefit from quantitative measures of skin pigmentation in sun exposed and non-exposed body sites, which were rarely considered in studies of vitamin D determinants 44,45 . This may be especially important in highly mixed populations. According to our results, both natural skin pigmentation as well as that resulting from sun exposure were associated with vitamin D concentrations in Brazilian adults. Of note, mean sun exposure index, an estimate 
of the individually received UV dose, was low if compared with others 33,45 suggesting little exposure despite the high sunlight availability in Rio de Janeiro. An additional exploration of our results revealed that, during winter months, mean sun exposure index (SEI) was higher among individuals who were vitamin D sufficient compared to those with serum 25(OH)D lower than 50nmol/L (data not shown). This is consistent with the potential for vitamin D status improvement with increased sun exposure even during the less favorable months for its synthesis.

The association between fat excess and lower vitamin D concentrations has been extensively studied; the most accepted hypothesis is the sequestration of the vitamin D by the adipose tissue 13,14. However, there is also evidence of a causal relationship in the opposite direction, suggesting that a poor vitamin $\mathrm{D}$ status contributes to fat mass accumulation 13,14. Regardless of the direction (or bidirection), fat mass in association with vitamin $\mathrm{D}$ may denote an intermediate step linking vitamin $\mathrm{D}$ deficiency with insulin resistance and metabolic syndrome 46 . Given that visceral adipose tissue is more closely related to those outcomes, it is desirable to investigate fat association with vitamin D considering its type and distribution. Previous studies have already suggested that low $25(\mathrm{OH}) \mathrm{D}$ concentrations are more strongly related to visceral than overall adiposity 15,16 which may be attributed to the higher secretion of pro-inflammatory adipokines by visceral fat and its potential effects on vitamin D binding proteins 16 . Accordingly, visceral fat mass - but not subcutaneous - was kept in the final regression model of our study.

The frequencies of genotypes determined by the evaluated SNPs were similar to those observed in other countries of Latin America (HapMap, The International HapMap Consortium). Among the studied SNPs, GC-rs2282679 was the only that appeared associated with serum $25(\mathrm{OH}) \mathrm{D}$, with the presence of the allele $\mathrm{C}$ being associated with lower concentrations. The allele $\mathrm{C}$ is considered the risk allele for having low vitamin D concentrations and had a frequency of $20 \%$ in our studied population. Previous studies have reported lower 25(OH)D concentrations in individuals carrying CC genotype 47,48 or higher concentrations in those carrying AA genotypes 49,50, for the $G C$-rs 2282679 . The $G C$ gene encodes the vitamin D binding protein (DBP) and, by influencing its synthesis and/or affinity with $25(\mathrm{OH}) \mathrm{D}$, it may ultimately affect the total $25(\mathrm{OH}) \mathrm{D}$ circulating levels.

Despite the efforts to consider a broad array of potential vitamin D determinants in Brazilian adults, the proportion of variance in serum $25(\mathrm{OH}) \mathrm{D}$ concentrations explained by the associated factors identified by regression analysis was low (23.3\%), similarly to some previous studies exploring non-genetic vitamin D determinants 39,40 . Our limited ability to explain $25(\mathrm{OH}) \mathrm{D}$ variability illustrates the difficulty of predicting circulating vitamin D levels in mixed populations. Given that genetic variants associated with $25(\mathrm{OH})$ D concentrations can be race-specific 33 , in mixed population such as ours, information on ancestry, rather than on selected SNPs, may provide more insights on vitamin $\mathrm{D}$ determinants.

For the first time in a Brazilian population, a simultaneous evaluation of potential environmental and genetic determinants of vitamin $D$ was conducted. Additional strengths of this study include the use of quantitative measures of skin pigmentation in a mixed-race population, as well as a good estimation of sun exposure evaluated by SEI. Also, the influence of body fat was explored in a specially refined way through the assessment of visceral and subcutaneous fat mass compartments. However, several limitations deserve consideration. First, we did not account for the potential influence of alcohol consumption and the presence of chronic diseases that have been described as associated with vitamin D. Second, as the information on SEI was limited to the assessment at the dorsum of the hand, additional information on clothing habits and sunscreen use would probably be more valuable for the estimation of whole body sun exposure. Third, 25(OH)D concentrations were not measured by the HPLC/MS/MS reference method. The LIAISON assay has been widely referred in literature and well accepted for determination of total 25(OH)D in serum in several population studies. Nevertheless, there is evidence that it may underestimate total 25(OH)D concentration if compared with the reference method and, therefore, overestimate (10-15\%) the prevalence of vitamin D insufficiency 51. Fourth, information on the use of vitamin D supplement was obtained from questions not directed to that specific purpose, which may have contributed to underreporting. Finally, exploration on the combination of genetic variants was limited by the sample size. 
This study provided an overall picture of genetic, sociodemographic, and lifestyle factors affecting vitamin D status in Brazilian adults. Despite being non-modifiable, some key factors, such as gender, skin type, and frequency distribution of GC genotypes need to be considered when evaluating prevalence of vitamin D insufficiency in mixed-race populations. Moreover, implications of visceral fat mass in association with vitamin $\mathrm{D}$ deserves attention given that both high visceral fat accumulation and poor vitamin D status are unfavorably related with health outcomes. We also provided evidence of the effect season of the year has over vitamin D status, even in regions where the seasons are usually unvalued. In theory, the highly available sunlight in Rio de Janeiro could compensate for the restricted vitamin D dietary intake. However, the low sun exposure index suggests that participants' lifestyle did not take advantage of the sun's availability for vitamin D status improvement.

\section{Contributors}

F. F. Bezerra contributed to the study conception and design, data analysis and interpretation, and writing. P. Normando and V. Zembrzuski contributed to the data acquisition, analysis and interpretation, and critical review. A. C. P. Fonseca, M. Campos-Junior, and P. H. Cabello-Acero contributed to the data acquisition, analysis and interpretation. E. Faerstein contributed to the study conception and design, data interpretation, and critical review. All authors approved the final version of the manuscript.

\section{Additional informations}

ORCID: Flávia Fioruci Bezerra (0000-0002-65944323); Paula Normando (0000-0002-6443-7733); Ana Carolina P. Fonseca (0000-0001-6123-0481); Verônica Zembrzuski (0000-0002-0044-3210); Mario Campos-Junior (0000-0002-7121-0748); Pedro Hernan Cabello-Acero (0000-0002-13895064); Eduardo Faerstein (0000-0002-4027-4896).

\section{Acknowledgments}

The authors acknowledge the assistance provided by members of Pró-Saúde research team and the staff of Interdisciplinary Nutritional Assessment Laboratory (Social Medicine Institute, State University of Rio de Janeiro) for DXA analyses.

\section{References}

1. Autier P, Mullie P, Macacu A, Dragomir M, Boniol M, Coppens K, et al. Effect of vitamin $\mathrm{D}$ supplementation on non-skeletal disorders: a systematic review of meta-analyses and randomised trials. Lancet Diabetes Endocrinol 2017; 12:986-1004.

2. Martineau AR, Jolliffe DA, Hooper RL, Greenberg L, Aloia JF, Bergman P, et al. Vitamin D supplementation to prevent acute respiratory tract infections: systematic review and metaanalysis of individual participant data. BMJ 2017; 356:i6583.

3. Hauger H, Laursen RP, Ritz C, Mølgaard C, Lind MV, Damsgaard CT. Effects of vitamin D supplementation on cardiometabolic outcomes in children and adolescents: a systematic review and meta-analysis of randomized controlled trials. Eur J Nutr 2020; 59:873-84.

4. Mithal A, Wahl DA, Bonjour JP, Burckhardt P, Dawson-Hughes B, Eisman JA, et al. Global vitamin D status and determinants of hypovitaminosis D. Osteoporos Int 2009; 20:1807-20.

5. Institute of Medicine, Food and Nutrition Board. Dietary reference intakes for calcium and vitamin D. Washington DC: National Academies Press; 2010.

6. Melamed ML, Astor B, Michos ED, Hostetter TH, Powe NR, Muntner P. 25-hydroxyvitamin $\mathrm{D}$ levels, race, and the progression of kidney disease. J Am Soc Nephrol 2009; 20:2631-9.

7. Williams SK, Fiscella K, Winters P, Martins D, Ogedegbe G. Association of racial disparities in the prevalence of insulin resistance with racial disparities in vitamin D levels: National Health and Nutrition Examination Survey (2001-2006). Nutr Res 2013; 33:266-71. 
8. Fiscella K, Winters P, Tancredi D, Franks P. Racial disparity in blood pressure: is vitamin $\mathrm{D}$ a factor? J Gen Intern Med 2011; 26:1105-11.

9. Hoteit M, Al-Shaar L, Yazbeck C, Sleiman MB, Ghalayini T, Fuleihan GE. Hypovitaminosis $\mathrm{D}$ in a sunny country: time trends, predictors, and implications for practice guidelines. Metabolism 2014; 63:968-78.

10. Manios Y, Moschonis G, Lambrinou CP, Tsoutsoulopoulou K, Binou P, Karachaliou A, et al. A systematic review of vitamin D status in southern European countries. Eur J Nutr 2018; 6:2001-36.

11. Mogire RM, Mutua A, Kimita W, Kamau A, Bejon P, Pettifor JM, et al. Prevalence of vitamin D deficiency in Africa: a systematic review and meta-analysis. Lancet Glob Health 2020; 8:e134-42.

12. Mendes MM, Darling AL, Hart KH, Morse S, Murphy RJ, Lanham-New SA. Impact of high latitude, urban living and ethnicity on 25-hydroxyvitamin D status: a need for multidisciplinary action? J Steroid Biochem Mol Biol 2019; 188:95-102.

13. Vimaleswaran KS, Berry DJ, Lu C, Tikkanen E, Pilz S, Hiraki LT, et al. Causal relationship between obesity and vitamin D status: bi-directional Mendelian randomization analysis of multiple cohorts. PLoS Med 2013; 2:e1001383.

14. Hajhashemy Z, Shahdadian F, Moslemi E, Mirenayat FS, Saneei P. Serum vitamin D levels in relation to metabolic syndrome: a systematic review and dose-response meta-analysis of epidemiologic studies. Obes Rev 2021; 22:e13223

15. Kühn T, Kaaks R, Teucher B, Hirche F, Dierkes J, Weikert C, et al. Dietary, lifestyle, and genetic determinants of vitamin D status: a cross-sectional analysis from the European Prospective Investigation into Cancer and Nutrition (EPIC)-Germany study. Eur J Nutr 2014; 53:731-41.

16. Rafiq R, Walschot F, Lips P, Lamb HJ, de Roos A, Rosendaal FR, et al. Associations of different body fat deposits with serum 25-hydroxyvitamin D concentrations. Clin Nutr 2019; 38:2851-7.

17. Lucas RM, Ponsonby AL, Dear K, Valery PC, Taylor B, van der Mei I, et al. Vitamin D status: multifactorial contribution of environment, genes and other factors in healthy Australian adults across a latitude gradient. J Steroid Biochem Mol Biol 2013; 136:300-8.

18. Bahrami A, Sadeghnia HR, Tabatabaeizadeh SA, Bahrami-Taghanaki H, Behboodi N, Esmaeili $\mathrm{H}$, et al. Genetic and epigenetic factors influencing vitamin D status. J Cell Physiol 2018; 233:4033-43.

19. Engelman CD, Meyers KJ, Ziegler JT, Taylor KD, Palmer ND, Haffner SM, et al. Genomewide association study of vitamin D concentrations in Hispanic Americans: the IRAS family study. J Steroid Biochem Mol Biol 2010; 122:186-92
20. Wang TJ, Zhang F, Richards JB, Kestenbaum B, van Meurs JB, Berry D, et al. Common genetic determinants of vitamin D insufficiency: a genome-wide association study. Lancet 2010; 376:180-8.

21. Lasky-Su J, Lange N, Brehm JM, Damask A, Soto-Quiros M, Avila L, et al. Genome-wide association analysis of circulating vitamin $\mathrm{D}$ levels in children with asthma. Hum Genet 2012; 131:1495-505.

22. Jiang X, O'Reilly PF, Aschard H, Hsu YH, Richards JB, Dupuis J, et al. Genome-wide association study in 79,366 European-ancestry individuals informs the genetic architecture of 25 hydroxyvitamin D levels. Nat Commun 2018; 9:260.

23. Touvier M, Deschasaux M, Montourcy M, Sutton A, Charnaux N, Kesse-Guyot E, et al. Determinants of vitamin D status in Caucasian adults: influence of sun exposure, dietary intake, sociodemographic, lifestyle, anthropometric, and genetic factors. J Invest Dermatol 2015; 135:378-88.

24. Yao S, Hong CC, Bandera EV, Zhu Q, Liu S, Cheng TYD, et al. Demographic, lifestyle, and genetic determinants of circulating concentrations of 25-hydroxyvitamin D and vitamin D-binding protein in African American and European American women. Am J Clin Nutr 2017; 105:1362-71.

25. Jolliffe DA, Hanifa Y, Witt KD, Venton TR, Rowe M, Timms PM, et al. Environmental and genetic determinants of vitamin D status among older adults in London, UK. J Steroid Biochem Mol Biol 2016; 164:30-5.

26. Faerstein E, Chor D, Lopes CS, Werneck GL. Estudo Pró-Saúde: características gerais e aspectos metodológicos. Rev Bras Epidemiol $2005 ; 8: 454-66$

27. Normando P, Santos-Rebouças C, Leung C, Epel E, Fonseca AC, Zembrzuski V, et al. Variants in gene encoding for vitamin $\mathrm{D}$ binding protein were associated with leukocyte telomere length: The Pró-Saúde Study. Nutrition 2020; 71:110618.

28. Rocha TF, Hasselmann MH, Curioni CC, Bezerra FF, Faerstein E. Alcohol consumption is associated with DXA measurement of adiposity: the Pró-Saúde Study, Brazil. Eur J Nutr 2017; 56:1983-91.

29. World Health Organization. Physical status: the use and interpretation of anthropometry. Report of a WHO Expert Committee. Geneva: World Health Organization; 1995.

30. Sichieri R, Everhart JE. Validity of a Brazilian food frequency questionnaire against dietary recalls and estimated energy intake. Nutr Res 1998; 18:1649-59.

31. U.S. Department of Agriculture. National nutrient database for standard reference. http:// ndb.nal.usda.gov/ndb/foods/list (accessed on 20/Mar/2015). 
32. Del Bino S, Sok J, Bessac E, Bernerd F. Relationship between skin response to ultraviolet exposure and skin color type. Pigment Cell Res 2006; 19:606-14.

33. Lock-Andersen J, Knudstorp ND, Wulf HC. Facultative skin pigmentation in caucasians: an objective biological indicator of lifetime exposure to ultraviolet radiation? Br J Dermatol 1998; 138:826-32.

34. Ernst AF, Albers CJ. Regression assumptions in clinical psychology research practice: a systematic review of common misconceptions. Peer J 2017; 5:e3323.

35. Lima-Costa MF, Mambrini JVM, de SouzaJunior PRB, Andrade FB, Peixoto SV, Vidigal $\mathrm{CM}$, et al. Nationwide vitamin D status in older Brazilian adults and its determinants: The Brazilian Longitudinal Study of Aging (ELSI). Sci Rep 2020; 10:13521.

36. Pereira-Santos M, Santos JYG, Carvalho GQ, Santos DB, Oliveira AM. Epidemiology of vitamin $D$ insufficiency and deficiency in a population in a sunny country: geospatial meta-analysis in Brazil. Crit Rev Food Sci Nutr 2019; 59:2102-9.

37. Freisling H, Fahey MT, Moskal A, Ocké MC, Ferrari P, Jenab M, Norat T, et al. Regionspecific nutrient intake patterns exhibit a geographical gradient within and between European countries. J Nutr 2010; 140:1280-6.

38. Peters BSE, Verly Jr. E, Marchioni DM, Fisberg M, Martini LA. The influence of breakfast and dairy products on dietary calcium and vitamin D intake in post pubertal adolescents and young adults. J Hum Nutr Diet 2012; 25:69-74.

39. Freedman DM, Cahoon EK, Rajaraman P, Major JM, Doody MM, Alexander BH, et al. Sunlight and other determinants of circulating 25-hydroxyvitamin D levels in black and white participants in a nationwide U.S. study. Am J Epidemiol 2013; 177:180-92.

40. Petrenya N, Lamberg-Allardt C, Melhus M, Broderstad AR, Brustad M. Vitamin D status in a multi-ethnic population of northern Norway: the SAMINOR 2 Clinical Survey. Public Health Nutr 2020; 23:1186-200.

41. Brock K, Huang WY, Fraser DR, Ke L, Stolzenberg-Solomon R, Peters U, et al. Low vitamin $\mathrm{D}$ status is associated with physical inactivity, obesity and low vitamin D intake in a large US sample of healthy middle-aged men and women.J Steroid Biochem Mol Biol 2010; 121:462-6.
42. Holick MF. Vitamin D: the underappreciated D-lightful hormone that is important for skeletal and cellular health. Curr Opin Endocrinol Diabetes 2002; 9:87-98.

43. Engelsen O. The relationship between ultraviolet radiation exposure and vitamin $\mathrm{D}$ status. Nutrients 2010; 2:482-95.

44. Sawicki CM, Van Rompay MI, Au LE, Gordon CM, Sacheck JM. Sun-exposed skin color is associated with changes in serum 25 -hydroxyvitamin $\mathrm{D}$ in racially/ethnically diverse children. J Nutr 2016; 146:751-7.

45. John EM, Schwartz GG, Koo J, Wang W, Ingles SA. Sun exposure, vitamin D receptor gene polymorphisms, and breast cancer risk in a multiethnic population. Am J Epidemiol 2007; 166:1409-19.

46. Strange RC, Shipman KE, Ramachandran S. Metabolic syndrome: a review of the role of vitamin $\mathrm{D}$ in mediating susceptibility and outcome. World J Diabetes 2015; 6:896-911.

47. Shao B, Jiang S, Muyiduli X, Wang S, Mo M, $\mathrm{Li}$ M, et al. Vitamin D pathway gene polymorphisms influenced vitamin D level among pregnant women. Clin Nutr 2018; 37:2230-7.

48. Slater NA, Rager ML, Havrda DE, Harralson AF. Genetic variation in CYP2R1 and GC genes associated with vitamin D deficiency status. J Pharm Pract 2018; 30:31-6.

49. Perna L, Felix JF, Breitling LP, Haug U, Raum E, Burwinkel B, et al. Genetic variations in the vitamin $\mathrm{D}$ binding protein and season-specific levels of vitamin D among older adults. Epidemiology 2013; 24:104-9.

50. Magnus MC, Miliku K, Bauer A, Engel SM, Felix JF, Jaddoe VWV, et al. Vitamin D and risk of pregnancy related hypertensive disorders: mendelian randomisation study. BMJ 2018; 361:k2167.

51. Rahme M, Al-Shaar L, Singh R, Baddoura R, Halaby G, Arabi A, et al. Limitations of platform assays to measure serum 25OHD level impact on guidelines and practice decision making. Metabolism 2018; 89:1-7. 


\section{Resumo}

Este estudo teve como objetivo investigar fatores associados com as concentrações séricas de 25-hidroxivitamina [25(OH)D] em adultos brasileiros de acordo com fatores sociodemográficos e de estilo de vida, assim como de polimorfismos de nucleotídeo único $(S N P s)$ relacionados à vitamina $D$. Este é um estudo transversal ( $n=491$; 34-79 anos; 251 mulheres) aninhado em uma coorte prospectiva (Estudo Pró-Saúde). Associações entre a 25(OH) $D$ sérica e características sociodemográficas, consumo alimentar, uso de suplementos, atividade física, estação do ano na coleta da amostra de sangue, gordura corporal, fototipo de pele, indice de exposição solar e SNPs CYP2R1-rs 10741657 e GC -rs2282679, explorados por regressão multilinear. A prevalência de $25(\mathrm{OH}) D$ sérica $<50 \mathrm{nmol} / \mathrm{L}$ foi $55 \%$. A concentração sérica de $25(\mathrm{OH}) \mathrm{D}$ foi menor entre mulheres ( $\beta=-4,38$; IC95\%: $-8,02 ;-0,74)$, individuos com mais gordura visceral $(\beta=-4,02$; IC95\%: -5,92; -2,12) e genótipos AC e CC para GC-rs 2282679 ( $\beta=-6,84$; IC95\%: - 10,09; -3,59e $\beta=-10,63$; IC95\%: - 17,52; $-3,74$, respectivamente). Os fatores associados diretamente à $25(\mathrm{OH})$ $D$ sérica incluíram os meses de verão $(\beta=20,14$; IC95\%: 14,38; 25,90), fototipo intermediário $(\beta=6,16$; IC95\%: 2,52; 9,80), maior exposição solar ( $\beta=0$,49; IC95\%: 0,22; 0,75), ingestão de vitamina $D(\beta=0,48$; IC95\%: 0,03; 0,93) e atividade física $(\beta=4,65$; IC95\%: 1,54; 7,76). Além de atividade física, dieta e exposição solar, fatores não modificáveis, tais como variantes do gene GC devem ser considerados na avaliação da deficiência de vitamina $D$ em populações miscigenadas. Além disso, merece atenção a associação entre a gordura visceral elevada e o pior estado de vitamina $D$, uma vez que ambas as condições implicam em desfechos de saúde desfavoráveis, tanto crônicos quanto agudos.

Vitamina D; Polimorfismo de Nucleotídeo Único; Gordura Visceral; Pigmentação da Pele

\section{Resumen}

Nuestro objetivo fue investigar factores asociados con la concentración sérica 25-hidroxivitamina $D[25(\mathrm{OH}) \mathrm{D}]$ en adultos brasileños, considerando factores sociodemográficos y de vida, así como también los polimorfismos de nucleótido único relacionados con la vitamina D (SNPs). Se trata de un estudio transversal ( $n=491$; 34- 79 años; 251 mujeres), anidado dentro de una cohorte prospectiva (Estudio Pro-Salud). Se investigaron las asociaciones entre concentración sérica $25(\mathrm{OH}) \mathrm{D}$ y características sociodemográficas, ingesta alimentaria, uso de suplementos, actividad física, estación del año de recogida de muestras de sangre, grasa corporal, tipo de piel, indice de exposición al sol, y SNPs CYP2R 1-rs 10741657 y GC-rs 2282679 mediante una regresión múltiple lineal. La prevalencia sérica $25(\mathrm{OH}) \mathrm{D}<50 \mathrm{nmol} / \mathrm{L}$ fue $55 \%$. La 25(OH)D sérica fue menor entre las mujeres ( $\beta=-4,38$; IC95\%: -8,02; -0,74), quienes tenian alta grasa visceral ( $\beta=-4,02$; IC 95\%: -5,92; -2,12), genotipos AC y CC para GC-rs 2282679 $(\beta=-6,84$; IC 95\%: - 10,09; -3,59 y $\beta=-10,63$; IC95\%: -17,52; $-3,74$, respectivamente). Los factores directamente asociados con la concentración sérica $25(\mathrm{OH}) D$ incluyeron verano $(\beta=20,14$; IC95\%: 14,38; 25,90), tipo de piel intermedia ( $\beta=6,16$; IC95\%: 2,52; 9,80), más alta exposición al sol ( $\beta=0$,49; IC95\%: 0,22; 0,75), toma de vitamina $D(\beta=0,48$; IC95\%: 0,03; 0,93) y actividad física $(\beta=4,65$; IC95\%: 1,54; 7,76). Además de la actividad física, dieta y exposición al sol, los factores no modificables, tales como genotipos GC, necesitan tenerse en cuenta cuando se está evaluando la insuficiencia de vitamina $D$ en poblaciones mestizas. Asimismo, las implicaciones de la asociación de una alta grasa visceral con un estatus más pobre de vitamina $D$ merece que se le preste atención, puesto que ambas condiciones de salud están relacionadas desfavorablemente con resultados de salud graves y crónicos.

Vitamina D; Polimorfismo de Nucleótido Simple; Grasa Intraabdominal; Pigmentación de la Piel
Submitted on $02 /$ Oct $/ 2020$

Final version resubmitted on 09/Apr/2021

Approved on 21/May/2021 